\title{
Exploring the Potential of Zakah for Supporting Realization of Sustainable Development Goals (SDGs) in Indonesia
}

\author{
Sarah Asmalia, Rahmatina Awaliah Kasri, and Abdillah Ahsan \\ Universitas Indonesia
}

\begin{abstract}
Sustainable Development Goals (SDGs) is a universal call to end poverty, protect the planet and ensure that all people enjoy peace and prosperity; goals which are strongly in line with the objective of Islam (maqasid al shariah). Despite of global acceptance of the concept, however, financing issues remain the biggest challenge for realizing the SDGs. Innovative financing through partnership with religious and other institutions, therefore, has been recommended. With this perspective, this study aims to explore the potential of zakah to support financing and realizing the goals in Indonesia. This is done by identifying factors that influence the intention of Muslims to pay zakah and exploring the SDGs' clusters prioritized to be financed from the zakah funds. The study collected primary data from 304 respondents living in Greater Jakarta area of Indonesia and utilized the Theory of Planned Behaviors (TPB) approach to frame the intentions. It also used descriptive statistics and Structural Equation Modeling (SEM) to analyze the data. The findings suggest that three TPB variables, namely attitudes, subjective norms and behavioral control, have a positive influence on the Muslims' intention to pay zakat. Additionally, attitudes are influenced by religiosity, knowledge and trust to zakah organizations. Furthermore, of the five objective clusters' in the SDGs, the people cluster (which includes objectives such as poverty reduction, education and health improvement) received the highest priority in the perceptions of the Muslims regarding the use of zakah for financing SDGs. The findings highlight the potential of zakah in supporting achievement of SDGs in Indonesia, something that might be useful for government, NGOs, zakah organizations and other zakah stakeholders.
\end{abstract}

Keywords: Zakah and SDGs; intention to pay zakah; Zakah in Indonesia; Financing of SDGs; Innovative Financing.

\section{INTRODUCTION}

The 2030 Agenda for Sustainable Development, known as the Sustainable Development Goals (SDGs), is a universal call to end poverty, protect the planet and ensure that all people enjoy peace and prosperity. The SDGs consists of 17 goals and 169 targets. They balance the economic, social and ecological dimensions of sustainable development, and place the fight against poverty and sustainable development on the same agenda for the first time (UN, 2018).
The universal call is responded positively worldwide and commitment to SDGs has been shown by many countries, including Indonesia. It is evident that President Joko Widodo's nine national priorities and the country's MediumTerm Development Plans (RPJMN) align well with the SDGs. Furthermore, after mapping the goals and targets of the national plan with the SDGs, the National Development Planning Agency (Bappenas) suggested that 108 out of 169 SDG targets are matched with the RPJMN (Brodjonegoro, 2018). 
Ending poverty and achieving the other objectives of SDGs, however, are no easy tasks. One major challenge for achieving the SGDs is limited financing. Traditionally, the funding comes from government budget, official development assistance and loans from multilateral financial institutions. Nevertheless, they are no longer sufficient for achieving the SDGs. World Economic Forum (2015) estimated that the current gap of investment (that is the difference between the total investment needed and the available traditional development fund) in critical sectors reached \$3.1 trillion. Therefore, it is necessary to further improve sources of fund through partnerships with private, religious and other sectors.

Zakah can be a supporting source of the fund because zakah is basically aimed at reducing poverty and ensuring social justice. In Islam, the vision of human welfare does not only revolve around the realization of income and wealth equity but also to fulfill spiritual and non-material needs in addition to sustaining long-term economic development (Chapra, 2008). The need for achieving this prosperity has been discussed in Islamic literature with the concept of maqasid al-shariah (the purpose of sharia). The reason for the existence of maqasid al-shariah is to fulfill the interests (jalb al-masalih) of all mankind and avoid danger (daf 'almafasid). Imam al-Ghazali classified the maqasid al-shariah into five main categories, namely protection of faith (din), life (nafs), intellect ('aql), lineage (nasl), and wealth (mal) (Chapra, 2008).

As the country with the largest Muslim population in the world, Indonesia has a very big zakah potential as well. According to the National Board of Zakat (BAZNAS) data in 2015, the potential of national zakah reached $\mathrm{Rp} 217$ trillion. However, the national zakah potential has not been achieved optimally. Until 2016, the total funding of zakah, infaq, and alms (ZIS) funds reached Rp5 trillion, 74.51 percent of which were zakah funds, accounting to more than Rp3.7 trillion. These figures show that the realization of zakah fund collection in Indonesia is still very far from its potential. Not only from the collection, the distribution of zakah funds needs to be developed. The total amount of ZIS funds distributed nationally reached Rp2.9 trillion in 2016, showing the absorption of 58.42 percent of funds collected. The absorption rate of national ZIS funds has decreased from the previous year, which was 61.6 percent (Pusat Kajian Strategis, 2016).

Table 1. Proportion of Zakah Allocation Fund based on Distribution Sectors

\begin{tabular}{|l|l|l|l|l|l|}
\hline No & \multicolumn{1}{|c|}{ Sectors } & \multicolumn{1}{|c|}{$\mathbf{2 0 1 5}$ (in Rupiah) } & $\boldsymbol{\%}$ & \multicolumn{1}{|c|}{$\mathbf{2 0 1 6}$ (in Rupiah) } & \multicolumn{1}{|c|}{} \\
\hline 1. & Economy & $338,030,622,008$ & 15.01 & $493,075,489,398$ & 18.30 \\
\hline 2. & Education & $458,195,272,997$ & 20.35 & $842,980,341,134$ & 31.28 \\
\hline 3. & Dakwah & $334,749,823,815$ & 14.87 & $418,454,281,897$ & 15.53 \\
\hline 4. & Health & $191,419,750,663$ & 8.50 & $226,004,399,823$ & 8.39 \\
\hline 5. & Social & $929,239,276,062$ & 41.27 & $714,267,956,361$ & 26.51 \\
\hline \multicolumn{2}{|l}{ TOTAL } & $2,251,634,745,545$ & 100 & $2,694,782,468,613$ & 100 \\
\hline
\end{tabular}

Source: Indonesia Zakat Outlook, 2017

With this perspective, this study aims to explore the potential of zakah to support financing and realizing the SDGs in Indonesia. This is done by identifying factors that influence the intention of Muslims to pay zakah and exploring the SDGs' clusters prioritized to be financed from the zakah funds. As far as we 
concern, few studies attempt to address this issue. While this is probably related to the fact that the SDGs is a relatively new global development agenda which was just issued in 2016, replacing the Millennium Development Goals (MDGs) ended in 2015. Not only that, linking zakah with SDGs is also a relatively new discourse in Islamic economics.

The study collected primary data from 304 respondents living in Greater Jakarta area of Indonesia and utilized the Theory of Planned Behaviors (TPB) approach to frame the intentions to pay zakah. It also used descriptive statistics and Structural Equation Modeling (SEM) to analyze the primary data and identifying the SDGs' clusters prioritized to be financed from the zakah funds.

To proceed, the paper is structured as follow. Section two reviews relevant literature and subsequently develop the relevant hypotheses. Section three explains the research methods, while section four discusses the findings and analyses. The final section makes conclusions and recommendations of the study.

\section{LITERATURE REVIEW AND HYPOTHESES DEVELOPMENT}

There have been a number of previous researches on the influence of the theory of planned behavior (TPB) factors on the behavior of paying zakah. Attitude, subjective norms, and perceived behavioral control have been shown to have positive and significant influence on the behavior of obedience to pay zakah (Al Jaffri Saad \& Haniffa, 2014; Azman \& Bidin, 2015; Haji-Othman, Alwi, Sheh Yusuff, \& Mohd Saufi, 2017; Idris, Bidin, \& Saad, 2012; Muhammad \& Saad, 2016;
Sapingi, Ahmad, \& Mohamad, 2011b). Other variables that are extensions of TPB such as knowledge, religiosity and trust also positively and significantly influence the behavior of paying zakah (Azman \& Bidin, 2015; Haji-Othman, Alwi, et al., 2017; Idris et al., 2012; Mukhlis \& Beik, 2013; Oladimeji Abioye Mustafa, Har Sani Mohamad, \& Akhyar Adnan, 2013).

This study extends the theory of planned behavior (TPB) proposed by Icek Ajzen. According to this theory, human behavior is guided by three considerations: beliefs about the possible consequences of behavioral beliefs, beliefs about normative beliefs, and beliefs about the existence of factors that may facilitate or impede the conduct of behaviors (control beliefs). From behavioral beliefs or behavioral beliefs then generate the desired or undesirable attitude toward the behavior (attitude toward the behavior); normative beliefs or normative beliefs produce social pressures or subjective norms, and beliefs of control or control beliefs result in perceived behavior control (perceived behavioral control). The combination of attitudes, subjective norms and perceived behavioral controls leads to the formation of behavioral intentions. TPB is an extension or development of a theory of reasoned action (TRA) previously proposed by Ajzen as well, by adding a perceived behavior control variable to the TPB. A person is expected to work on their intentions when the opportunity arises so that intentions or intentions are assumed to be antecedents that immediately lead to behavior. However, many difficult behaviors that can limit the control of the will (volitional control), so that perceived behavioral control should be considered in addition to intention (Ajzen, 2005). 
Figure 1. The conceptual framework of the theory of planned behavior (TPB)

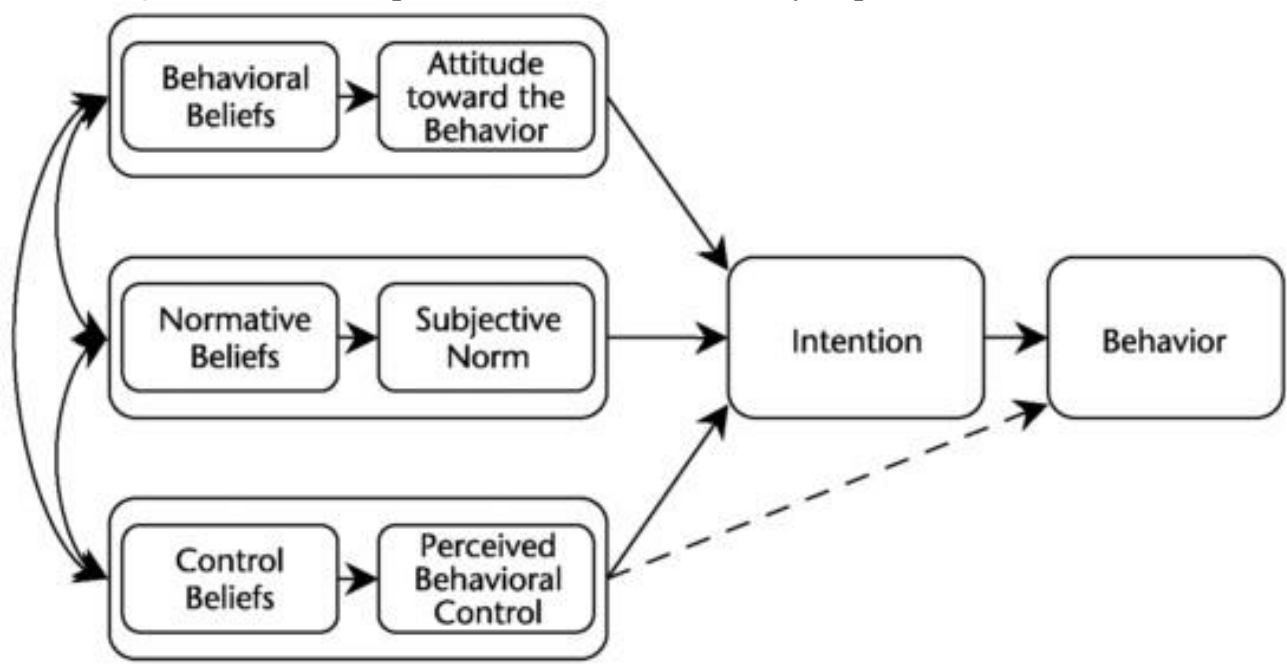

Source: Ajzen, 2005

\section{Attitude toward zakah and intention}

Attitude towards a behavior can be defined as a person's tendency to assess positively or negatively a behavior. According to TPB, attitude towards a behavior is determined by accessible beliefs about the consequences of the behavior. This is commonly referred to as behavioral beliefs. Any behavioral belief links behaviors with certain outcomes or other attributes such as the cost incurred from performing such behavior. Attitude towards a behavior is determined by a combination of behavioral beliefs and outcome evaluation. These two factors can be found in the salient belief of a behavior. Salient belief is a common assumption used by a particular group to assess a behavior. The evaluation of each salient belief influences the attitude in proportion to the subjective probability that the behavior will produce a questionable result.

Several studies have been conducted to examine the effect of attitude on behavior to pay zakah. Azman \& Bidin (2015) and Haji-Othman, Alwi, Yusuff \& Saufi (2017) found that attitude has a significant effect on compliance behavior to pay zakah on income. Saad and Haniffa (2014) found that the intention, influenced by attitude and subjective norms, became a significant predictor of compliance behavior to pay zakah. In other words, the intention becomes a mediator of the influence of attitude and subjective norms. Hence, the following hypothesis is proposed:

\section{H1. Attitude towards zakah has a positive influence on the intention of muzakki to pay zakah}

The behavior observed in this research is towards paying zakah. Thus, the salient beliefs are religiosity, trust, and knowledge.

\section{Religiosity}

Religiosity means religious devotion or piety. Meanwhile, McDaniel and Burnett (1990) define religiosity as "belief in God accompanied by a commitment to follow the principles believed to be ordained by God." Another definition for religiosity is the condition or state of being religious (O'Brien \& Palmer 1993). Religiosity is a multidimensional concept and encompasses the various elements of religion which are beliefs, practices, knowledge, experiences, and effects of such elements on everyday activities (O'Connell, 1975).

Several studies have shown that religiosity has a significant positive and 
significant influence on the intention to pay zakah(Haji-Othman, Alwi, et al., 2017; Haji-Othman, Sheh Yusuff, Mohd Saufi, \& Hafsha, 2017; Idris et al., 2012). Religiosity also has a positive influence on investor behavior in Sukuk especially during Ramadan (Klein, Turk, \& Weill, 2017). Religiosity also has a minimal but statistically positive and significant influence on compliance to pay voluntary taxes (Mohdali \& Pope, 2014). Meanwhile, the study of Azman and Bidin (2015) shows that religiosity is not a factor that is so important to the behavior of zakah paying compliance, which is probably caused by paying directly to mustahik instead of to the zakah amil institution (LAZ). However, religiosity still shows a positive influence on compliance to pay zakah(Azman \& Bidin, 2015). Thus, the next hypothesis that is formed is:

H2. Religiosity has a positive influence on the attitude of the muzakki towards the intention of muzakki to pay zakah

Trust

Etymologically, the term trust is defined as the assumption or belief that something that is believed to be true or real. Meanwhile, the term trust usually refers to a situation marked by one party (trustor) who is willing to rely on the actions of another party (trustee) (Mayer, Davis, \& Schoorman, 1995; Walter, 2010). In this study, trust is the extent to which the trust muzakki has to amil (manager) of zakah.

Some previous studies have proven that information on zakah and taxes influence the payment of zakah or taxes. The perception of firm credibility - in which case the level of trust muzakki has for zakah agencies - also positively and significantly change the behavior to pay zakah(Azman \& Bidin, 2015). Thus, the following hypothesis is:
H3. Trust towards zakah agencies has a positive influence on the attitude of muzakki towards the intention to pay zakah

Knowledge

Ajzen (2005) explains that knowledge can influence an individual's attitude toward a behavior. In this study, knowledge refers to muzakki's knowledge on the concept and utilization of zakah.

Knowledge is an important component that can influence attitudes and perceptions (Fallan, 1999). Previous research has also shown that knowledge has an influence on the behavior of paying taxes or zakah. Knowledge of taxes has an influence on tax awareness and compliance to pay taxes (Andreas \& Savitri, 2015). Knowledge also has a positive and significant influence on the intention to pay zakah(Haji-Othman, Sheh Yusuff, et al., 2017). In the case of charity giving, it was found that people with higher levels of education tend to be more charitable or give donations (Awaliah Kasri, 2013). The hypothesis which then formed is as follows:

H4. Knowledge of zakah has a positive influence on the attitude of muzakki towards the intention to pay zakah

\section{Subjective norm and intention}

Ajzen (1991) defines subjective norms as the perceived social pressure when conducting a behavior. The subjective norm refers to a person's perception of a relevant opinion from others about whether to perform the behavior. "References" that are important for influencing include parents, spouses, close friends, co-workers, and, depending on the behaviors involved, experts. The belief underlying subjective norms is called normative belief. In general, the person who believes that his referenced figure approves of a behavior will do the behavior. Conversely, when most of the 
references do not approve of the behavior, it will put pressure on someone to avoid the behavior. Motivation to meet the expectations of the reference is called motivation to comply. Subjective norms can be assessed directly by asking respondents to assess how likely that most people who are important to them will agree on the behavior given (Ajzen, 1991). Thus, the next hypothesis is as follows:

\section{H5. Subjective norm has a positive influence on the intention of muzakki to pay zakah}

\section{Perceived behavioral control and intention}

Perceived behavioral control has an important role in TPB, which is also a variable that differentiates TPB from TRA. The current concept of perceived behavioral control is in accordance with Bandura's concept of self-efficacy (1977, 1982), in which one's behavior is strongly influenced by their self-confidence in their own ability to do so. TPB places the construction of self-efficacy or perceived behavioral control beliefs within a more general framework of relationships between beliefs, attitudes, intentions, and behaviors(Ajzen et al., 1991).
According to TPB, perceived behavior control with intention can predict the attainment of a behavior. There are at least two reasons that support the hypothesis. First, assuming constant intention attempts to resolve a behavior tend to increase with perceived behavioral control. Second, perceived behavior control can often be used as a substitute to measure actual control over a behavior. Perceived behavioral control becomes less realistic when the information possessed about the behavior is minimal or when there are foreign elements entering the situation of the behavior. However, when its behavioral control is realistic, it can be used to predict the success of the behavior (Ajzen, 1985 in Ajzen, 1991). Thus, the hypothesis is formed as follows:

\section{H6. Perceived behavioral control has a positive influence towards the intention of muzakki to pay zakah}

Based on the literature reviewed, the conceptual framework for determining the factors affecting the intentions to pay zakah is developed and illustrated in Figure 2. While the research methods, including for identifying the SDGs' clusters prioritized to be financed from the zakah funds, will be discussed in the next section.

Figure 2. Conceptual framework of the research

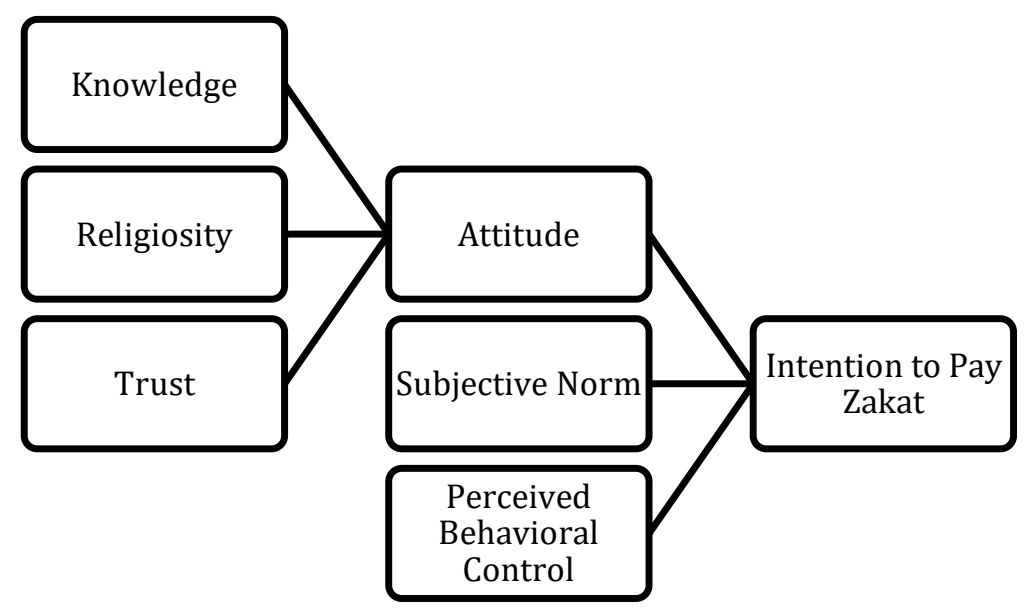




\section{RESEARCH METHOD}

\section{Research Design}

The research approach used in this research is the quantitative approach. A quantitative approach is an approach that emphasizes the hypothesis test, where the analyzed data are measured and will produce a generalizable conclusion. This type of research is descriptive, where in general this research will explain the factors that become the determinants of intention of muzakki to pay zakah with the theory of planned behavior (TPB) approach and describing the SDGs' clusters prioritized to be financed from the zakah funds.

\section{Population and Sampling}

The target sample in this study is taken from elements of the Muslim population in Indonesia who have already paid zakah (muzakki), in particular, income zakah. In this study, the sample size used refers to the opinion of Hair et al. (2006) that the sample size in the study should have a minimum number of five times the number of questions or statements to be analyzed. Therefore, the number of respondents used in this study is a minimum of 185 samples, obtained from 37 statements multiplied by five.

The sampling method used is the non-probability sampling, where the type of non-probability sampling selected is convenience sampling and purposive sampling. With convenience sampling technique, samples are selected from the population element that is easy to reach by researchers. Meanwhile, with purposive sampling, the sample is selected based on the assessment or criteria that have been determined by the researchers in accordance with the purpose of the study. Because the research of interest in this study is the intention of paying zakah, then the sample is taken from the Muslim population who have paid zakah (muzakki) in Indonesia. The criteria determined are Muslims in Indonesia who have paid income zakah in the past year.

The data is collected through a survey using an online questionnaire consisting of five parts. The first part contains a screening question. The second section contains questions related to respondents' demographic data. The third section contains general questions that include the zakah behavior of respondents. The fourth section contains statements related to each dimensions of the TPB included in the research indicator, using the Likert scale with five choices of strongly disagreeing (option 1) to strongly agree (option 5). The final section contains questions related to the SDGs sectors prioritized to be financed from the zakah funds. It should also be noted that the questionnaires are distributed online through social media to facilitate the acquisition of the number of respondents required.

\section{Data Analysis}

\section{Sample Profile}

The author distributed an online questionnaire for three weeks and obtained345 respondents. Of the 345 respondents, 41 respondents did not pass the screening questions (not / have not paid zakah profession in the past year) and/or data did not meet the research needs (partial or incomplete data input). In the end, 304 respondent data were used for processing. From the data obtained, 53 percent of respondents are men while female respondents as much as 47 percent. The majority of respondents are in the age range of 20-30 years, as many as 49 percents of the total respondents. Of the total respondents, the proportions of both married and unmarried respondents are similar, where each category holds 48 percent of the total respondents, while the rest are divorced (5 percent). The majority of respondents work as private employees, 
as many as 44 percents of the total respondents.

Structural Equation Modelling (SEM)

Structural Equation Modeling (SEM) is an analytical method that combines three simultaneous analysis approaches: checking the validity and reliability of the instrument (factor analysis), testing the relationships between models (path analysis), and finding the most suitable model for regression estimation (structural analysis). SEM uses various models to illustrate relationships among variables (be it observed variables and/or latent variables, independent or dependent), with the basic purpose of providing quantitative testing of theoretical models hypothesized by the researcher.

In the SEM analysis, there are two model analyses. First, the measurement model is the initial model used to see how big the indicators are able to represent latent variables. Second is the structural model which shows the dependency relationship between latent variables.

\section{Measurement Model Analysis}

To know whether the indicator can actually be used as an indicator of the latent variable, it is necessary to test the measurement model. The form of analysis performed to test the measurement model consists of the validity test, reliability test, and goodness of fit test. Validity test is a test conducted to test or measure the accuracy of indicators in representing latent variables. Validity test is done by looking at the value of the standard loading factor and t-value indicator shown in the path diagram using LISREL software. An indicator is stated to have good validity if it is known: (1) t-value in factor loading is more than 1.64; and (2) the value of the standardized loading factor $(\lambda)$ on each indicator is worth more than 0.5 .

Meanwhile, the reliability test is a statistical test performed to determine the consistency of a measurement model by looking at the value of construct reliability $(\mathrm{CR})$ and variance extracted value (VE). In general, a construct or latent variable is considered to have good reliability if the $\mathrm{CR}$ value is greater than 0.70 and the $\mathrm{VE}$ value is more than equal to 0.50 . However, Hatcher (2013) and Fornell and Larcker in Huang et al. (2013) also believes that a VE value below 0.50 is still acceptable for CR values above 0.60 (Santoso, 2017).

A goodness of fit test is a measure used to evaluate how well measurement models are able to represent data. If the goodness of fit produced by a model is good, then the model is acceptable, and vice versa (Latan, 2012 in Santoso, 2017). According to Hair, et al. (2010), using three to four measures of goodness of fit is considered sufficient to assess the suitability of the model. The tables showing several measures of goodness of fit used in this study can be seen in the Results and Discussion section.

Structural Model Analysis

A structural model is a model showing the relationship between latent variables. Through structural model, researchers can see the causal relationship between exogenous latent variables and exogenous latent variables so as to determine whether the research hypothesis is accepted or rejected. The structural model analysis consists of the goodness of fit test and hypothesis test.

The goodness of fit test performed on the structural model is similar to the goodness of fit test on the measurement model, that is to see how the research model is able to produce estimation that represents the data in the field. Meanwhile, a hypothesis test is done to prove the hypotheses that have been determined by the researcher and to the see the significance of influence between latent variables. A hypothesis test is done by looking at the values of the following measures:

- $t$-value $> \pm 1.64$ with a $5 \%$ level of significance, one-tailed (due to the 
hypothesized relationships is oneway). The t-value is used to see the effect of latent variables on other latent variables.

- The coefficient of the estimate, where the value indicates the direction of the relationship between latent variables (positive or negative).

\section{Descriptive Statistics}

Descriptive statistics are used to describe the basic features of the data in a study. They provide simple summaries about the sample and the measures. In the context of this study, descriptive statistics are used to describe and compare the results of the questions related to the SDGs sectors prioritized to be financed from the zakah funds.

\section{FINDINGS AND DISCUSSIONS}

\section{Measurement Model Analysis}

\section{Validity Test Result}

The t-value results found that all indicators passed the test except the indicator of the ease of paying zakah with current income (PBC4). While the standard loading test results indicate that all statements pass the test except the indicators of routine presence in religious study groups (REL6), the ease of paying zakah with current income (PBC4), the control of zakah paying behavior (PBC6), and the interest of paying zakah in the future INT1). After knowing what indicators did not pass the validity test, the next step is the process of dropping by removing the indicators that did not meet the standards of validity. For standard loading and t-value results before and after the process of dropping variables can be seen in the appendix.

\section{Reliability Test Result}

Based on the test results in the table above, the value of the construct reliability of all latent variables has met the criteria of good reliability except for the intention (INT), the value of construct reliability of which reached 0.65 . Thus, it can be said that the reliability for intention is weak, but all latent variables of research other than the intention already meet the reliability standards of a research model. Meanwhile, the values of variance extracted of attitude (ATT), trust (TRU), and subjective norm (SN) already meet the criteria of reliability above 0.50. However, Hatcher (2013) and Fornell and Larcker in Huang et al. (2013) argue that a VE value below 0.50 is still acceptable for CR values above 0.60 (Santoso, 2017). Thus, referring to the argument, it can be argued that all the latent variables are reliable.

Table 2. Summary of Reliability Test Results of the Measurement Model

\begin{tabular}{|l|l|l|l|l|l|l|l|}
\hline & ATT & KNO & REL & TRU & SN & PBC & INT \\
\hline CR & 0.802268 & 0.788612 & 0.818434 & 0.918283 & 0.863876 & 0.773544 & 0.652274 \\
\hline VE & 0,509067 & 0.350427 & 0.427807 & 0.692517 & 0.517832 & 0.461409 & 0.486873 \\
\hline
\end{tabular}

Goodness of Fit Test Result

The next step is to test the goodness of fit in the measurement model. The goodness of fit test is conducted to evaluate the suitability or suitability of the data with the model.

Table 3. The result of the goodness of fit test of the measurement model

\begin{tabular}{|l|l|l|}
\hline The goodness of fit indices & Good Fit Score & Model Score \\
\hline $\begin{array}{l}\text { Root Mean Square Error of } \\
\text { Approximation }(\text { RMSEA) }\end{array}$ & RMSEA model $\leq 0.08$ & $\mathbf{0 . 0 7 9}$ \\
\hline Incremental Fit Index (IFI) & IFI model $\geq 0.80$ & $\mathbf{0 . 8 3}$ \\
\hline
\end{tabular}




\begin{tabular}{|l|l|l|}
\hline Comparative Fit Index (CFI) & CFI model $\geq 0.80$ & $\mathbf{0 . 8 3}$ \\
\hline Normed Chi-Square & $1.0 \leq N h^{2} \leq 5.0$ & $\mathbf{2 . 8 9}$ \\
\hline $\begin{array}{l}\text { Parsimonious Goodness of Fit } \\
\text { Index (PGFI) }\end{array}$ & $>0.60$ & $\mathbf{0 . 6 5}$ \\
\hline $\begin{array}{l}\text { Consistent Akaike Information } \\
\text { Criterion(CAIC) }\end{array}$ & $\begin{array}{l}\text { The value of the CAIC positive } \\
\text { model is closer to the saturated } \\
\text { CAIC than CAIC independence }\end{array}$ & $\begin{array}{l}\text { Model CAIC: } 1990.98 \\
\text { Saturated CAIC: } \mathbf{3 7 6 8 . 2 5}\end{array}$ \\
\hline
\end{tabular}

Based on the results in the table, there are four measures of goodness of fit that indicate the value of good fit and two measures that show the value of marginal fit. According to Hair, et al. (2010), using three to four measurement indices is sufficient to prove that the model fits. Therefore, it can be said that the measurement model has been able to present the data well.

\section{Structural Model Analysis}

Goodness of Fit Test Result

Table 4. The result of the goodness of fit test of the structural model

\begin{tabular}{|l|l|l|}
\hline The goodness of fit indices & Good Fit Score & Model Score \\
\hline $\begin{array}{l}\text { Root Mean Square Error of } \\
\text { Approximation }(\text { RMSEA) }\end{array}$ & RMSEA model $\leq 0.08$ & $\mathbf{0 . 0 8 9}$ \\
\hline Incremental Fit Index (IFI) & IFI model $\geq 0.80$ & $\mathbf{0 . 8 0}$ \\
\hline Comparative Fit Index (CFI) & CFI model $\geq 0.80$ & $\mathbf{0 . 8 0}$ \\
\hline Normed Chi-Square & $1.0 \leq N$ Ch $\leq 5.0$ & $\mathbf{3 . 3 8}$ \\
\hline $\begin{array}{l}\text { Parsimonious Goodness of Fit } \\
\text { Index (PGFI) }\end{array}$ & $>0.60$ & $\mathbf{0 . 6 5}$ \\
\hline $\begin{array}{l}\text { Consistent Akaike Information } \\
\text { Criterion(CAIC) }\end{array}$ & $\begin{array}{l}\text { The value of the CAIC positive } \\
\text { model is closer to the saturated } \\
\text { CAIC than CAIC independence }\end{array}$ & $\begin{array}{l}\text { Model CAIC: } \mathbf{2 1 6 9 . 4 8} \\
\text { Independence CAIC: } \mathbf{6 4 5 7} .34\end{array}$ \\
\hline
\end{tabular}

Of the six measurements, there are three measurements that have a degree of marginal fit and three measurements that have a good fit degree. According to Hair, et al. (2010), using three to four measurement indices is sufficient to prove that the model fits. Thus, it can be said that the structural model of the study can represent the data well.

\section{Hypothesis Test Result}

According to Wijanto (2008), the value of the standardized loading factor or the estimated coefficient of $>1$ is considered negative and requires respecification. However, based on the results of hypothesis testing, it can be seen that all exogenous latent variables in the research model are able to have a positive and significant influence on endogenous latent variables.

Table 5. Summary of the results of the hypothesis test on the structural model

\begin{tabular}{|l|l|l|l|}
\hline Path & Estimated coefficient & $\boldsymbol{t}$-value & Conclusion \\
\hline KNO $\rightarrow$ ATT & 0.83 & 9.20 & Positive and significant influence \\
\hline REL $\rightarrow$ ATT & 1.00 & 13.72 & Positive and significant influence \\
\hline TRU $\rightarrow$ ATT & 0.58 & 9.41 & Positive and significant influence \\
\hline ATT $\rightarrow$ INT & 0.79 & 12.07 & Positive and significant influence \\
\hline SN $\rightarrow$ INT & 0.49 & 6.32 & Positive and significant influence \\
\hline
\end{tabular}




\begin{tabular}{|l|l|l|l|}
\hline $\mathrm{PBC} \rightarrow \mathrm{INT}$ & 0.85 & 11.11 & Positive and significant influence
\end{tabular}

\section{Preferred SDGs Sectors}

Table 6 below summarizes the survey results regarding the respondents' preferences towards the SDGs sectors that could be prioritized from the zakah funds. Based on the results of the data obtained, it is known that respondents placed the
People sector as the main priority sector in achieving the SDGs, followed by the Prosperity sector. The Peace sector is the third priority sector, followed by the Planet sector and the Partnership sector to be the last priority sector chosen by respondents for the achievement of the Goals stated in the SDGs.

Table 6. Respondents' Preference to Priority Sectors for Achieving Sustainable Development Goals

\begin{tabular}{|l|c|c|c|}
\hline \multicolumn{1}{|c|}{ Category } & Rank & Score & $\begin{array}{c}\text { Number of } \\
\text { Respondents }\end{array}$ \\
\hline $\begin{array}{l}\text { People (Eradicating poverty, hunger, } \\
\text { healthy and prosperous life, quality } \\
\text { education, gender equality, clean water } \\
\text { and proper sanitation) }\end{array}$ & $\mathbf{1}$ & 1.123 & 304 \\
\hline $\begin{array}{l}\text { Prosperity (Clean and affordable energy, } \\
\text { decent work and economic growth, } \\
\text { industry, innovation and infrastructure, } \\
\text { reducing inequality, sustainable cities } \\
\text { and communities) }\end{array}$ & $\mathbf{2}$ & 823 & 304 \\
\hline $\begin{array}{l}\text { Peace } \text { (Peace, justice and strong } \\
\text { institutions for a just, peaceful and } \\
\text { inclusive society) }\end{array}$ & $\mathbf{3}$ & 687 & 304 \\
\hline $\begin{array}{l}\text { Planet (Consumption and production that } \\
\text { are responsible, handling climate change, } \\
\text { marine and terrestrial ecosystems) }\end{array}$ & $\mathbf{4}$ & 547 & 304 \\
\hline $\begin{array}{l}\text { Partnership (Global partnership to } \\
\text { achieve Sustainable Development Goals) }\end{array}$ & $\mathbf{5}$ & 480 & 304 \\
\hline
\end{tabular}

What is interesting from the results of these data is the ranking of the Peace sector on the Planet, indicating that Muslims in Indonesia, represented by respondents, still choose sectors related to social welfare as a priority in achieving development goals. This finding is in accordance with previous findings conducted by the BAZNAS Strategic Study Center in the 2018 Indonesian Zakat Outlook. The BAZNAS Strategic Study Center divides the zakat distribution channel into five main sectors, namely economics, education, da'wah, health, and social humanity. It was found that in 2015 , the largest proportion of zakat funds was given to the social humanitarian sector, with a percentage of 41.27 percent of the total zakat funds channeled. The second field that receives the largest distribution of zakat funds is the education sector with a percentage of 20.35 percent of the total zakat funds channeled. However, in the following year it was found that the education sector became the field with the largest proportion of zakat funding, which amounted to 31.28 percent of the total zakat funds channeled in 2016, followed by the social humanitarian sector with a percentage of 26.51 percent of total zakat funds channeled during the year (BAZNAS Strategic Study Center, 2018). This indicates that the priority of utilizing zakat funds among Muslim communities in Jabodetabek is still focused on sectors that support social welfare, as reflected in the Goals in the People and Prosperity sectors. 


\section{CONCLUSIONS AND RECOMMENDATIONS}

This study found three latent variables that influence attitude towards zakah, namely knowledge towards zakah, religiosity, and trust towards zakah institution. This study also found that attitude, subjective norm and perceived behavioral control influence Muslims' intention of paying zakah. This also implies that knowledge, religiosity, and trust have an indirect influence towards the intention of paying zakah. This is in line with prior research conducted on the influence of the latent variables previously mentioned towards the intention of paying zakah (Aji, 2013; Al Jaffri Saad \& Haniffa, 2014; Haji-Othman, Alwi, et al., 2017; Haji-Othman, Sheh Yusuff, et al., 2017; Muhammad \& Saad, 2016; Nuryana, 2016; Sareye \& HajiOthman, 2017). The findings are also consistent with those reported in previous studies in other fields such as waqf donation and paying taxes (Mohdali \& Pope, 2014; Osman, 2014; Rizal \& Amin, 2017; Saad, 2014; Shukor et al., 2017). In general, this study confirms the suitability and application of the TPB in the zakah context. Variables highlighted in TPB, such as attitudes, subjective norms, and perceived behavioral control and intention, play an important role in explaining the behavior towards paying zakah.

The research findings have implications for both theory and practice. Compared to previous research, this study found that subjective norm does not have a very high influence on the intention of paying zakah, whereas perceived behavioral control is one of the biggest factors along with attitude. In terms of theoretical implication, the findings indicate that the construct of subjective norms and perceived behavioral control cannot be generalized to all types of environments, objects of research and population.

In terms of practical implications, zakah institutions need to put more effort in encouraging Muslims to pay zakah through zakah institutions as the majority of Muslims still pay their zakah directly to those who are in need (mustahik). As religiosity and perceived behavioral control are two factors that mainly influence the intention to pay zakah, it is important for zakah institutions to promote the value of religiosity and ease of access to the zakah payers. By promoting the importance of paying zakah as it is an obligatory act in Islam, and the easiness of paying through zakah institutions, the Muslim public can be more convinced that paying zakah through zakah institutions bring more benefit than harm for both the zakah payers and the zakah recipients. Zakah institutions should also focus on increasing communication between the amil (zakah collectors) and the zakah payers. This can help increase the Muslim public's awareness towards paying zakah and their intention to do so.

Furthermore, based on estimates made in the study, zakat funds are also found to have the potential to support the achievement of SDGs in Indonesia. Of the five priority sectors, the majority preference for muzakki in Jabodetabek falls to the People sector, which includes alleviating poverty and hunger, healthy and prosperous life, quality education, gender equality, clean water and proper sanitation. This indicates that the priority of the Muslim community in Jabodetabek is still in the social sphere of humanity, including poverty alleviation, realizing social welfare, good education and decent water and sanitation facilities for all. The second priority sector that becomes the muzakki preference in Jabodetabek for the contribution of zakat funds is the Prosperity sector (clean and affordable energy, decent work and economic growth, industry, innovation and infrastructure, reducing inequality, cities and sustainable communities). The third priority preference is Planet (responsible consumption and production, handling climate change, terrestrial and marine 
ecosystems), followed by Partnership (international partnerships to reach SDGs), and the last priority sector is Peace (peace, justice and strong institutions for a just, peaceful and inclusive society). The findings highlight the potential of zakah in supporting achievement of SDGs in Indonesia, something that might be useful for government, NGOs, zakah organizations and other zakah stakeholders.

\section{REFERENCES}

Aji, H. (2013). Intensi Muzakki Membayar Zakah Pendekatan Teori Planned Behaviour Modifikasi (Studi Terhadap Pegawai Kementerian Agama Pusat). Universitas Indonesia.

Ajzen, I. (1991). The theory of planned behavior. Organizational Behavior and Human Decision Processes, 50 , 179-211. https://doi.org/10.1016/07495978(91)90020-T

Ajzen, I. (2005). Attitudes, Personality, and Behaviour (Second). Berkshire: Open University Press. Retrieved from https://psicoexperimental.files.wor dpress.com/2011/03/ajzeni-2005attitudes-personality-andbehaviour-2nd-ed-open-universitypress.pdf

Ajzen, I., O'Connor, D., Michie, S., Josephson, V., Murphy, M., Brown, K., ... Vienne, D. de. (1991). The theory of planned behavior. Organizational Behavior and Human Decision Processes. https://doi.org/10.1016/07495978(91)90020-T

Al Jaffri Saad, R., \& Haniffa, R. (2014). Determinants of zakah (Islamic tax) compliance behavior. Journal of Islamic Accounting and Business Research, 5(2), 182-193. https://doi.org/10.1108/JIABR-10-
2012-0068

Andreas, \& Savitri, E. (2015). The Effect of Tax Socialization, Tax Knowledge, Expediency of Tax ID Number and Service Quality on Taxpayers Compliance With Taxpayers Awareness as Mediating Variables. Procedia - Social and Behavioral Sciences, 163-169.

Awaliah Kasri, R. (2013). Giving behaviors in Indonesia: motives and marketing implications for Islamic charities. Journal of Islamic Marketing, 4(3), 306-324. https://doi.org/10.1108/JIMA-052011-0044

Azman, F. M. N., \& Bidin, Z. (2015). Zakah Compliance Intention Behavior on Saving. International Journal of Business and Social Research, 5(1), 118-128.

Badan Pusat Statistik. (2017). Berita Resmi Statistik. Keadaan Ketenagakerjaan Indonesia Agustus Keadaan Ketenagakerjaan Indonesia Agustus. XX, 11(103), 112. Retrieved from https://www.bps.go.id/

Fallan, L. (1999). Gender, Exposure to Tax Knowledge, and Attitudes Towards Taxation; An Experimental Approach. Journal of Business Ethics, 18(2), 173-184. https://doi.org/DOI: 10.13140/2.1.1808.5762

Haji-Othman, Y., Alwi, I., Sheh Yusuff, M. S., \& Mohd Saufi, M. S. A. (2017). The Influence of Attitude, Subjective Norm, and Islamic Religiosity on Compliance Behavior of Income Zakah Among Educators. International Journal of Academic Research in Business and Social Sciences, 7(11), 11101116.

Haji-Othman, Y., Sheh Yusuff, M. S., Mohd Saufi, M. S. A., \& Hafsha, S. (2017). The Influence of Knowledge, Islamic Religiosity and Self- Efficacy on the Intention 
to Pay Income Zakah among Public Educators in Kedah, Malaysia. International Journal of Academic Research in Business and Social Sciences, 7(11), 1117-1127. https://doi.org/10.6007/IJARBSS/v 7-i11/3550

Idris, K. M., Bidin, Z., \& Saad, R. A. J. (2012). Islamic religiosity measurement and its relationship with business income zakah compliance behavior. Jurnal Pengurusan, 34, 3-10.

Klein, P. O., Turk, R., \& Weill, L. (2017). Religiosity vs. well-being effects on investor behavior. Journal of Economic Behavior and Organization, 138, 50-62. https://doi.org/10.1016/j.jebo.2017. 04.009

Mayer, R. C., Davis, J. H., \& Schoorman, F. D. (1995). An Integrative Model of Organizational Trust. Academy of Management Review, 20(3), 709-734.

https://doi.org/10.5465/amr.1995.9 508080335.

Mohdali, R., \& Pope, J. (2014). The influence of religiosity on taxpayers' compliance attitudes. Accounting Research Journal, 27(1), 71-91. https://doi.org/10.1108/ARJ-082013-0061

Muhammad, S. A., \& Saad, R. A.-J. (2016). Moderating Effect of Attitude toward Zakah Payment on the Relationship between Moral Reasoning and Intention to Pay Zakah. Procedia - Social and Behavioral Sciences, 219, 520527.

https://doi.org/10.1016/j.sbspro.20 16.05.029

Mukhlis, A., \& Beik, I. S. (2013). Analisis Faktor-Faktor yang Memengaruhi Tingkat Kepatuhan Membayar Zakah: Studi Kasus Kabupaten Bogor. Jurnal Al-Muzara'ah, I(1), 83-106.
Nuryana, F. (2016). Pengaruh Sikap, Norma Subjektif Dan Kontrol Perilaku Terhadap Niat Kepatuhan Muzakki Pegawai Negeri Sipil (PNS) Dalam Membayar Zakah Profesi Pada Badan Amil Zakah (BAZ) Kabupaten Sumenep. Nuansa, 13(2), 383-416.

Oladimeji Abioye Mustafa, M., Har Sani Mohamad, M., \& Akhyar Adnan, M. (2013). Antecedents of zakah payers' trust in an emerging zakah sector: An exploratory study. Journal of Islamic Accounting and Business Research, 4(1), 4-25. https://doi.org/10.1108/175908113 11314267

Osman, A. F. (2014). an Analysis of Cash Waqf Participation Among Young. 9th International Academic Conference, (April), 572-584.

Pusat Kajian Strategis. (2016). OUTLOOK ZAKAH INDONESIA 2017. Jakarta.

Rizal, H., \& Amin, H. (2017). Perceived Ihsan, Islamic egalitarianism and Islamic religiosity towards charitable giving of cash waqf. Journal of Islamic Marketing, 8(4), 669-685.

https://doi.org/10.1108/JIMA-052015-0037

Saad, N. (2014). Tax Knowledge, Tax Complexity, and Tax Compliance: Taxpayers' View. Procedia - Social and Behavioral Sciences, 109(1), 1069-1075. https://doi.org/10.1016/j.sbspro.20 13.12 .590

Santoso, B. I. (2017). Minat Masyarakat Pesantren Di Kabupaten Garut Terhadap Bank Syariah: Aplikasi Theory Of Planned Behavior.

Sapingi, R., Ahmad, N., \& Mohamad, M. (2011a). A study on zakah of employment income: Factors that influence academics' intention to pay zakah. 2nd International Conference On Business and Economic Research, (April), 2492- 
2507.

Sapingi, R., Ahmad, N., \& Mohamad, M. (2011b). A STUDY ON ZAKAH OF EMPLOYMENT INCOME: FACTORS THAT INFLUENCE ACADEMICS' INTENTION TO PAY ZAKAH, (2). Retrieved from https://www.researchgate.net/profil e/Noormala_Ahmad/publication/25 4399300_A_STUDY_ON_ZAKAH _OF_EMPLOYMENT_INCOME_ FACTORS_THAT_INFLUENCE_ ACADEMICS' INTENTION TO _PAY_ZAKAH/links/555469b808a eaaff3bf1be55.pdf

Sareye, J. M., \& Haji-Othman, Y. (2017). The Influence of Attitude, Subjective Norms and Service Quality on Intention to Pay Business Zakah Among Single Business Owners at Kuala Ketil, Malaysia. International Journal of Novel Research in Humanity and Social Sciences, 4(1), 100-107.

Shukor, S. A., Anwar, I. F., Aziz, S. A., \& Sabri, H. (2017). Muslim attitude towards participation in cash WAQF: Antecedents and consequences. International Journal of Business and Society, 18(S1), 193-204.

Walter, B. (2010). Interpersonal Trust Attempt of a Definition. Retrieved from http://www.ldv.ei.tum.de/en/resear ch/fidens/interpersonal-trust/

Sarah Asmalia

Universitas Indonesia

Indonesia

sarah.asmalia@ui.ac.id

Rahmatina Awaliah Kasri

Universitas Indonesia

Indonesia

rahmatina@ui.ac.id

Abdillah Ahsan

Universitas Indonesia

Indonesia

Abdillah.ahsan@ui.ac.id 


\section{APPENDICES}

Appendix A - Path diagrams of the measurement model

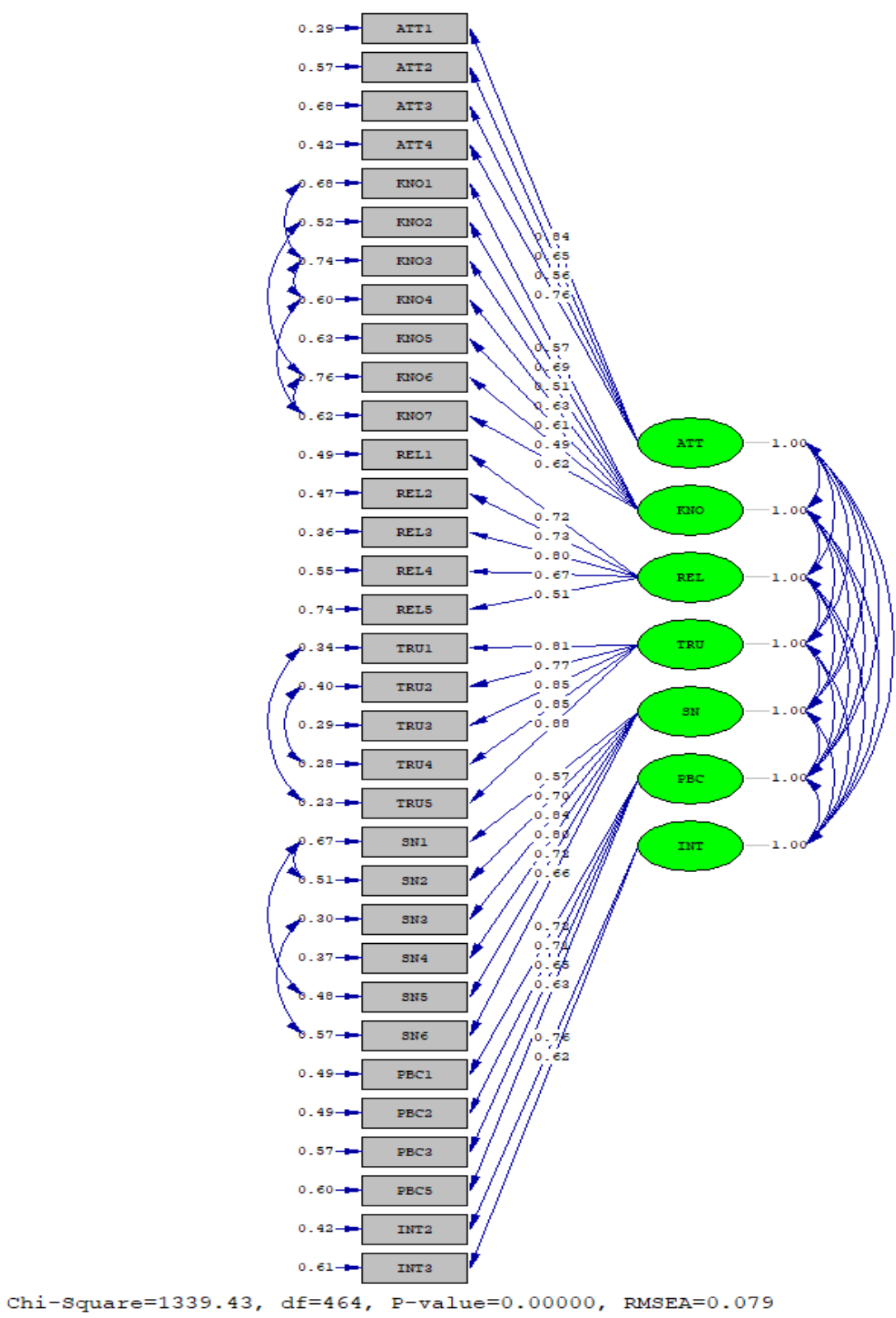

(a) standardized solution values of the measurement model 


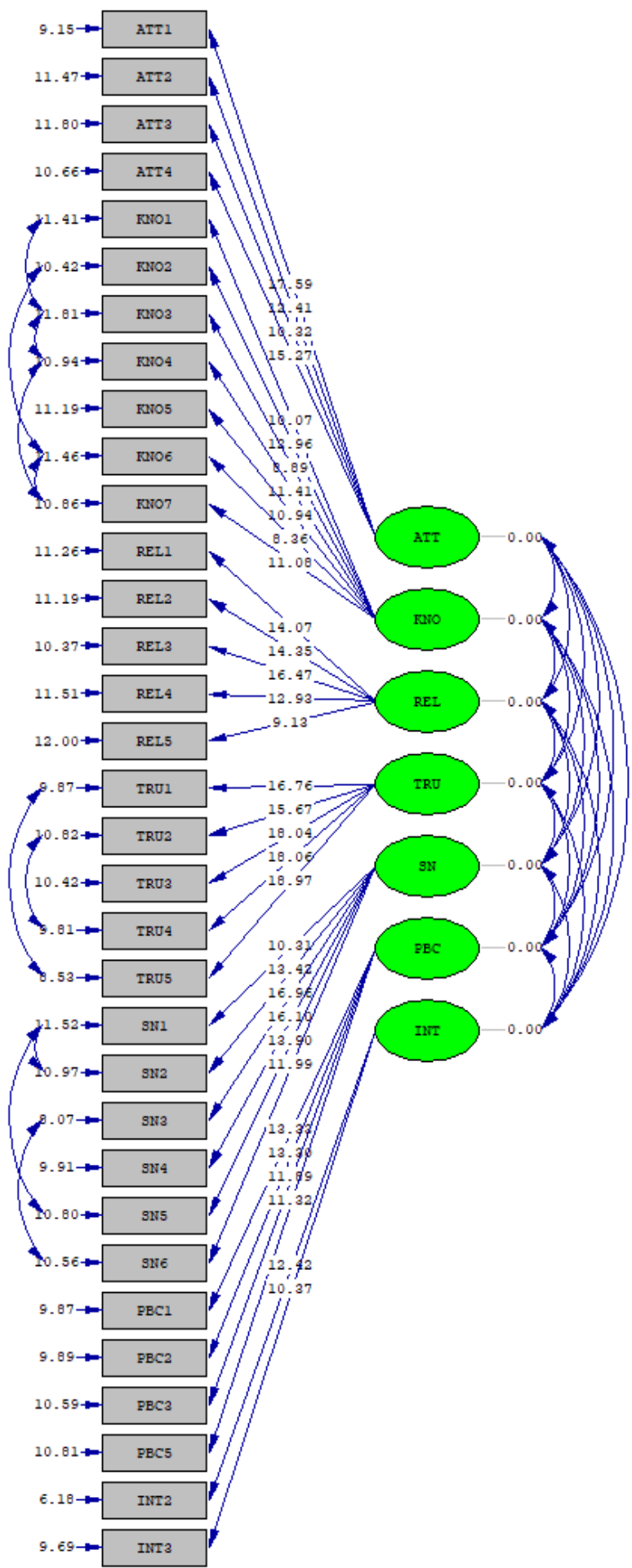

Chi-Square=1339.43, $\mathrm{df}=464, \mathrm{P}$-value $=0.00000, \mathrm{RMSEA}=0.079$

(b) t-statistics values of the measurement model 
Appendix B - Path diagrams of the structural model

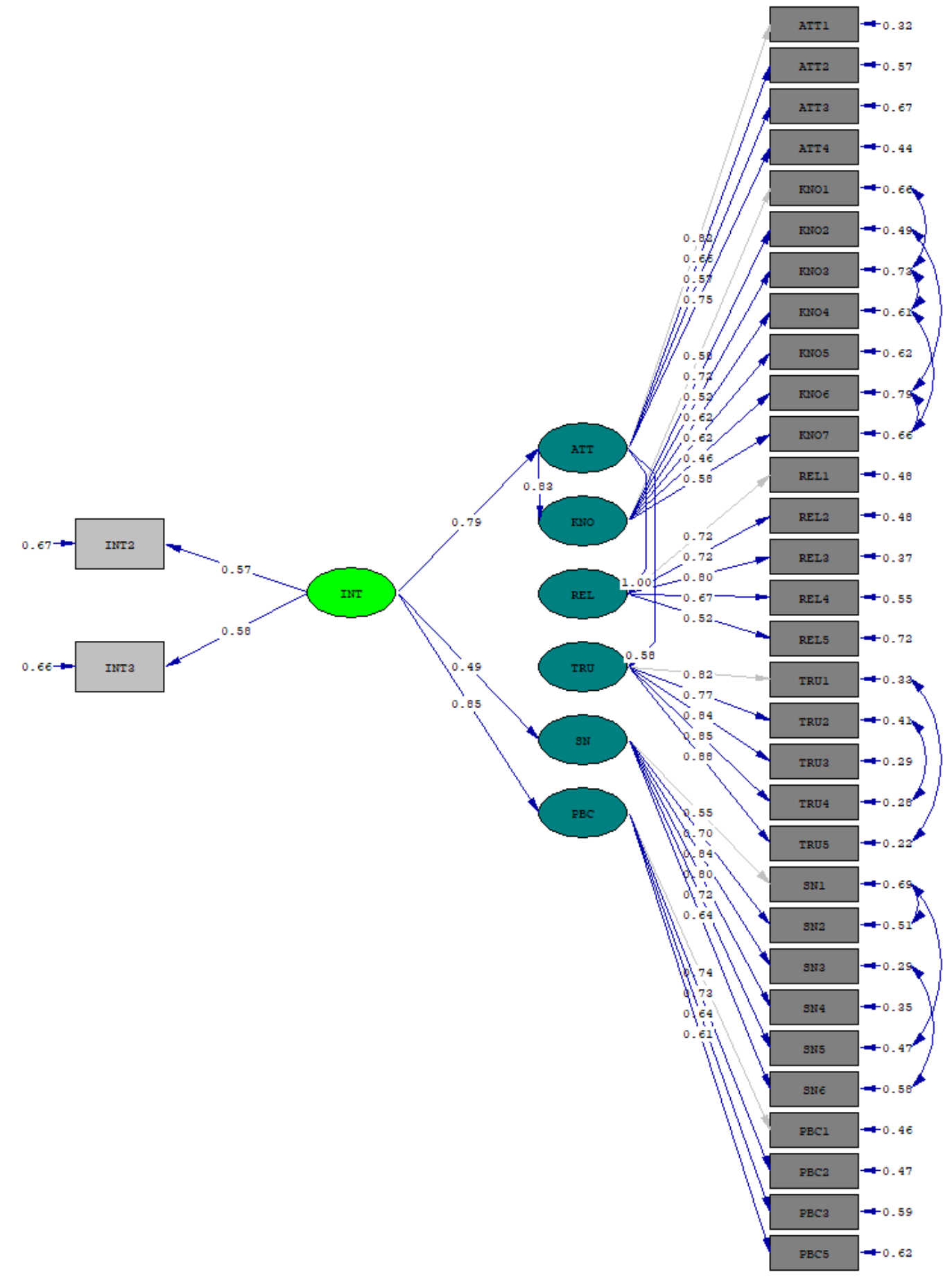

Chi-Square $=1618.69, \mathrm{df}=479, \mathrm{P}-\mathrm{value}=0.00000, \mathrm{RMSEA}=0.089$

(a) standardized solution values of the structural model 


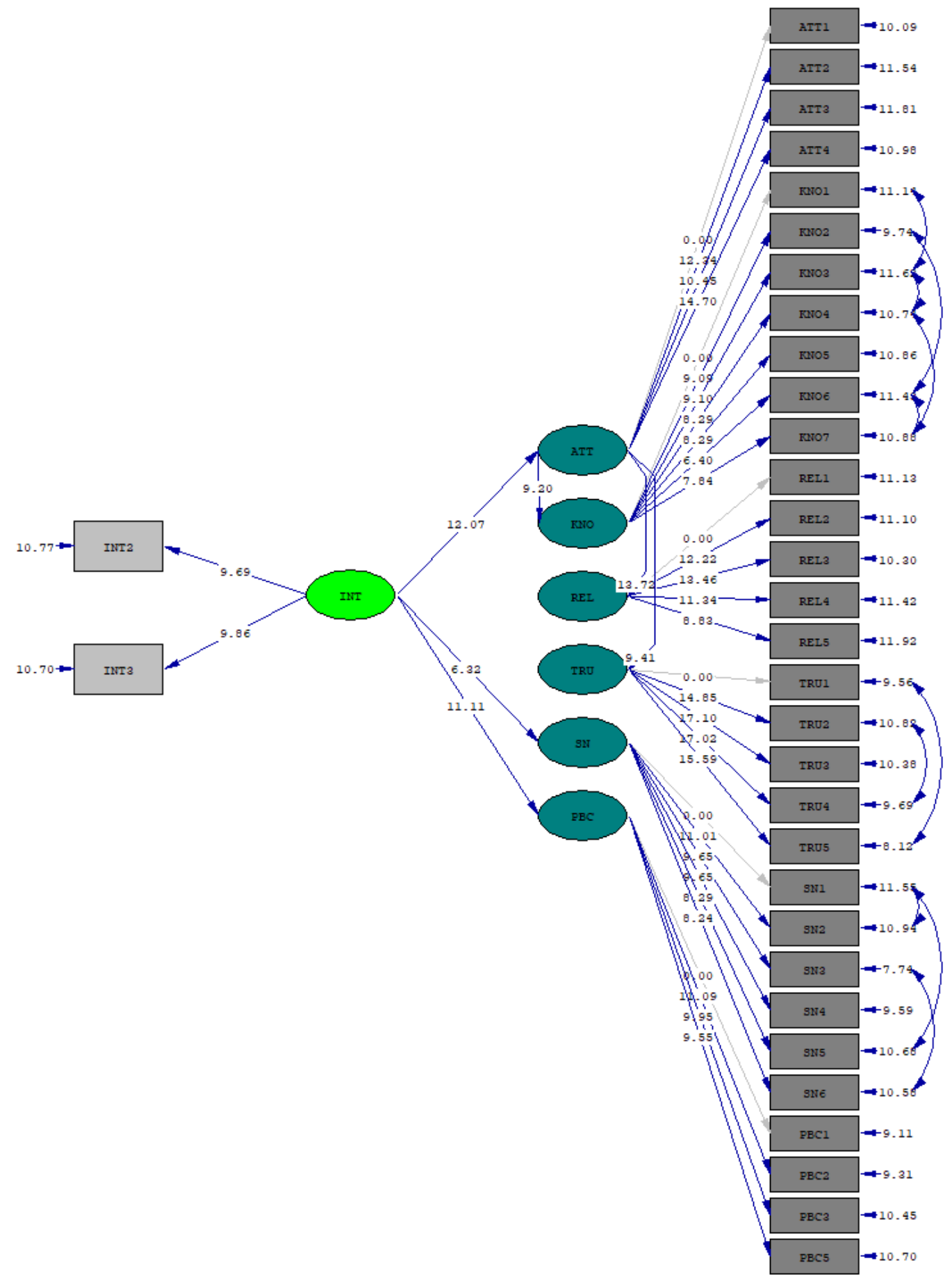

Chi-Square $=1618.69, d f=479, \mathrm{P}-$ value $=0.00000, \mathrm{RMSEA}=0.089$

(b) t-statistics values of the structural model 
